\title{
Erythropoietin rs1617640 G allele associates with an attenuated rise of serum erythropoietin and a marked decline of hemoglobin in hepatitis $C$ patients undergoing antiviral therapy
}

Ahmad Amanzada ${ }^{1 *+}$, Armin D Goralczyk ${ }^{1,2+}$, Lars Reinhardt ${ }^{1}$, Federico Moriconi ${ }^{1}$, Silke Cameron ${ }^{1}$ and Sabine Mihm ${ }^{1 *}$

\begin{abstract}
Background: A decline in hemoglobin $(\mathrm{Hb})$ concentration during antiviral therapy in chronic hepatitis $\mathrm{C}(\mathrm{CHC})$ is a serious side effect. It may compel to dose reduction or even termination of antiviral treatment. The activation of erythropoietin (EPO) synthesis as a physiological response to anemia and its relation to a genetic variation within the EPO gene has not been evaluated yet.

Methods: Data of 348 CHC patients were reviewed retrospectively. Samples were genotyped for EPO rs 1617640 and inosine triphosphatase (ITPA) rs1127354. Serum EPO concentrations were determined before and during therapy. Primary endpoints were set as $\mathrm{Hb}$ decline $>3 \mathrm{~g} / \mathrm{dl}$ at weeks 4 and 12 .

Results: EPO rs1617640 G homozygotes showed a significantly lower rise of serum EPO level over time than T allele carriers $(p<0.001)$. The cumulative frequency of a significant $\mathrm{Hb}$ reduction added up to $40 \%$. Multivariate analysis revealed that besides age, ribavirin starting dose and baseline $\mathrm{Hb}$ also EPO rs1617640 G homozygosity associates with $\mathrm{Hb}$ reduction at week $4(p=0.025)$ and $12(p=0.029)$, while ITPA C homozygotes are at risk for $\mathrm{Hb}$ decline particularly early during treatment. Furthermore, EPO rs1617640 G homozygotes were more frequently in need for blood transfusion, epoetin-a supplementation, or ribavirin dose reduction $(p<0.001)$.

Conclusions: Our data suggest that EPO rs1617640 genotype, the rise of serum EPO concentration as well as ITPA rs1127354 genotype are promising parameters to evaluate the Hb decline during antiviral therapy. A rational adjustment of therapy with epoetin-a supplementation might prevent serious adverse events or the need to terminate treatment.
\end{abstract}

Keywords: Anemia, Chronic hepatitis C virus infection, Ribavirin, EPO promoter polymorphism rs1617640, ITPA rs1127354

\section{Background}

Antiviral combination therapy consisting of pegylated interferon- $\alpha$ and ribavirin (PEG-IFN- $\alpha /$ RBV) for treatment of chronic hepatitis $\mathrm{C}$ virus (CHC) infection is highly effective but it is also difficult to tolerate in some patients. In fact, it is associated with significant morbidity and with treatment-limiting adverse events [1]. One

\footnotetext{
* Correspondence: ahmad.amanzada@med.uni-goettingen.de; smihm@med.uni-goettingen.de

${ }^{\dagger}$ Equal contributors

'Department of Gastroenterology and Endocrinology, University Medical Center Goettingen, Robert-Koch-Strasse 40, 37075 Goettingen, Germany Full list of author information is available at the end of the article
}

important treatment-limiting adverse event is anemia. In various prospective trials dose modification of RBV because of hemoglobin $(\mathrm{Hb})$ reduction were required in $9 \%$ up to $22 \%$ of patients $[2,3]$ affecting the overall treatment outcome. Recently, clinical studies assessing efficacy of $\mathrm{HCV}$ protease inhibitors in combination with PEG-IFN- $\alpha /$ RBV revealed an even higher rate of anemia ranging between $27 \%-46 \%[4,5]$. Moreover, the need to administer erythropoietin (EPO) was also increased about two-fold (up to $46 \%$ of boceprevir-treated vs $21 \%$ of controls) [5].

\section{Ciomed Central}

(c) 2014 Amanzada et al.; licensee BioMed Central Ltd. This is an Open Access article distributed under the terms of the Creative Commons Attribution License (http://creativecommons.org/licenses/by/4.0), which permits unrestricted use, distribution, and reproduction in any medium, provided the original work is properly credited. The Creative Commons Public Domain Dedication waiver (http://creativecommons.org/publicdomain/zero/1.0/) applies to the data made available in this article, unless otherwise stated. 
IFN- $\alpha$ monotherapy may induce a significant and rapid $\mathrm{Hb}$ decrease most probably caused by bone marrow inhibition [6]. RBV, by contrast, contributes to anemia by increasing hemolysis [7]. Several reports have examined serum EPO levels during antiviral treatment and could show an increase up to 4-fold at week 4 in patients treated with PEG-IFN- $\alpha_{2 a}$ and RBV while $\mathrm{Hb}$ levels are declining [8-12]. In the study by Trivedi et al. [10] the mean EPO serum level increased from $14.5 \pm 15.1$ at baseline to $58.5 \pm 94.1 \mathrm{mIU} / \mathrm{ml}$ at week 4 in 43 chronic $\mathrm{HCV}$ infected patients treated with antiviral combination therapy. Durante et al. [12] investigated EPO serum concentrations during antiviral combination therapy related to $\mathrm{Hb}$ decrease in 18 chronic $\mathrm{HCV}$ patients. The mean EPO serum level at the $\mathrm{Hb}$ nadir was $55.5 \pm$ $30.5 \mathrm{mIU} / \mathrm{ml}$. Another study could also show that the median EPO serum level increased at week 12 to 41 $\mathrm{mIU} / \mathrm{ml}$ (range $12-683 \mathrm{mIU} / \mathrm{ml}$ ) in 145 patients with chronic hepatitis C during PEG-IFN- $\alpha$ and RBV therapy $[9,10]$. Of note, a genetic variation within the EPO gene promoter region, rs1617640, was reported to be related to EPO concentration in the vitreous body fluid of nondiabetic patients [13]. In 2010, a genome-wide association study revealed that two functional variants in the inosine triphosphatase (ITPA) gene causing ITPA deficiency protect against RBV-induced hemolytic anemia and the need for RBV dose reduction in patients with HCV genotype 1 infection [14]. Recently, various studies could confirm these findings in $\mathrm{CHC}$ genotype 1 to 4 infected patients [15-18]. ITPA variants could predict $\mathrm{Hb}$ decline during therapy in patients treated with PEGIFN- $\alpha / R B V$ as well as in patients treated Telaprevir and PEG-IFN- $\alpha /$ RBV [19]. However, the exact mechanism of $\mathrm{Hb}$ reduction under combined antiviral therapy in $\mathrm{CHC}$ patients is still not fully understood.

This study sought to extend the understanding of $\mathrm{Hb}$ decline in $\mathrm{CHC}$ patients undergoing antiviral combination therapy. For this purpose, $\mathrm{Hb}$ and serum EPO concentrations were monitored before and at week 4, 8 and 12 after onset of antiviral combination therapy and related to EPO rs1617640 and ITPA rs1127354 genotypes.

\section{Methods}

\section{Patients and inclusion criteria}

Patients were included in this retrospective analysis in which core data and samples were collected before and on treatment. Inclusion criteria for this analysis were HCV-RNA positivity for more than 6 months, treatment with PEG-IFN- $\alpha$ and RBV, age 18 years or older, and compensated liver disease (Child-Pugh score $<7$ ). Also blood samples for genotyping and complete data sets for pre- and on-treatment (week 4, 8 and 12) $\mathrm{Hb}$ values had to be available. Patients with active hepatitis B virus or human immunodeficiency virus infection, continued alcohol or drug abuse and those who also received immunosuppressive drug agents were excluded from the study. 348 patients fulfilled the above criteria and were included in the analysis. This study was approved by the ethics committee of the University Medical Center of Goettingen (initial approval number 4/8/93 and subsequent amendments). All patients gave their written informed consent to participate in the study in accordance with the ethical guidelines of the 1975 Declaration of Helsinki. Patients also gave their written informed consent to perform EPO rs1617640 and ITPA rs1127354 genetic testing. Further disease chronicity was defined histopathologically by using established criteria [20]. In patients, who refused liver biopsy, chronicity was documented by longitudinal observation and/or the results of clinical, biochemical and imaging results. Before the initiation of therapy, a liver biopsy was obtained from 249 patients. On the basis of histological, biochemical and imaging results 48 individuals had evidence of severe fibrosis and cirrhosis. 15 out of 99 individuals who refused liver biopsy had indirect signs of cirrhosis by clinical, biochemical and imaging results.

\section{Treatment regimen and definition of efficacy}

Patients received 1 of 3 treatment regimens (Table 1): (1), PEG-IFN- $\alpha_{2 b} 1.5 \mu \mathrm{g} / \mathrm{kg} /$ week (wk) (standard dose) or (2), PEG-IFN- $\alpha_{2 b} 1.0 \mu \mathrm{g} / \mathrm{kg} / \mathrm{wk}$ (low dose), both in combination with oral RBV dosed by body weight $(40-65 \mathrm{~kg}$, $800 \mathrm{mg} /$ day; >65- $85 \mathrm{~kg}, 1000 \mathrm{mg} /$ day; >85- $105 \mathrm{~kg}$, $1200 \mathrm{mg} /$ day; >105-125 kg, $1400 \mathrm{mg} /$ day); or (3), PEGIFN- $\alpha_{2 a} 180 \mu \mathrm{g} /$ wk plus oral RBV 1000 - $1200 \mathrm{mg} /$ day dosed by body weight ( $<75 \mathrm{~kg}, 1000 \mathrm{mg} /$ day; $\geq 75 \mathrm{~kg}$, $1200 \mathrm{mg} /$ day). RBV dose was adjusted to body weight but not to viral genotypes, according to two recent studies in the field $[21,22]$. PEG-IFN- $\alpha_{2 a}$ and PEG-IFN- $\alpha_{2 b}$ dose was reduced when WBC and/or platelet counts fell below $1,500 \times 10^{3}$ cells $/ \mu \mathrm{l}$ or $50,000 \times 10^{3}$ cells $/ \mu \mathrm{l}$ respectively. Dose modifications of weekly PEG-IFN- $\alpha_{2 a}$ were made by decremental adjustments of $180 \mu \mathrm{g}$ to $135 \mu \mathrm{g}$ and $90 \mu \mathrm{g}$. PEG-IFN- $\alpha_{2 b}$ dose was reduced to $1.0 \mu \mathrm{g} / \mathrm{kg} /$ week or replaced by $0.5 \mu \mathrm{g} / \mathrm{kg} /$ week PEG-IFN- $\alpha_{2 \mathrm{~b}}$. RBV dose was reduced if $\mathrm{Hb}$ was $<10 \mathrm{~g} / \mathrm{dl}$ or when patients complained of symptoms. Dose modification of daily RBV dose was performed in decrements of $200 \mathrm{mg}$.

\section{Data collection and treatment of anemia}

Clinical examination, total blood cell counts and routine biochemical tests and efficacy assessments were performed during the treatment period every 2 weeks during the first 12 weeks, then four-weekly until week 48 and, finally, at weeks 4 and 24 during follow-up. At these time-points, serum samples were obtained and stored at $-20^{\circ} \mathrm{C}$ until further use. Serum samples were collected from 2003 to 2012. 
Table 1 Baseline patient characteristics $(n=348)$

\begin{tabular}{|c|c|}
\hline Female sex, n (\%) & $126(36)$ \\
\hline Age [median (IQR)] years & $50(43-58)$ \\
\hline Ethnicity Caucasian, n (\%) & $346(99)$ \\
\hline HCV genotype 1/2/3 (\%) & 240/25/83 (69/7/24) \\
\hline ALT [median (IQR)] U/I & $49(28-86)$ \\
\hline $\mathrm{Hb}[$ median (IQR)] g/dl & $15.1(14.2-16)$ \\
\hline Creatinine $[$ median (IQR)] mg/dl & $0.8(0.7-0.9)$ \\
\hline $\mathrm{EPO}^{\#}[$ median $(\mathrm{IQR})] \mathrm{mlU} / \mathrm{m}^{*}$ & $7.8(6-10.5)$ \\
\hline Hepatitis activity mild, $\mathrm{n}(\%)$ & $170(68)$ \\
\hline Fibrosis absent or mild, n (\%) & $201(81)$ \\
\hline Severe Fibrosis or Cirrhosis ${ }^{1}, \mathrm{n}(\%)$ & $63^{1}(18)$ \\
\hline Steatosis absent or mild, $\mathrm{n}(\%)$ & $224(90)$ \\
\hline \multicolumn{2}{|l|}{ Initial daily RBV dose ${ }^{2}, \mathrm{n}(\%)$} \\
\hline $800 \mathrm{mg}$ & $37(10)$ \\
\hline $1.000 \mathrm{mg}$ & $125(36)$ \\
\hline $1.200 \mathrm{mg}$ & $110(32)$ \\
\hline $1.400 \mathrm{mg}$ & $76(21)$ \\
\hline \multicolumn{2}{|l|}{ PEG-IFN-a treatment, $\mathrm{n}(\%)$} \\
\hline PEG-IFN- $a_{2 a}$ & $238(68)$ \\
\hline PEG-IFN- $a_{2 b} 1.0 \mu \mathrm{g} / \mathrm{kg}$ & $30(9)$ \\
\hline PEG-IFN- $a_{2 b} 1.5 \mu \mathrm{g} / \mathrm{kg}$ & $80(23)$ \\
\hline SVR by genotype $1 / 2 / 3, \mathrm{n}(\%)$ & $101 / 20 / 68(42 / 80 / 82)$ \\
\hline EPO rs1617640 TT/TG/GG, n (\%) & $113 / 168 / 67(33 / 48 / 19)$ \\
\hline ITPA rs1127354 CC/CA/AA, n (\%) & 280/66/2 (80/19/1) \\
\hline \multicolumn{2}{|c|}{$\begin{array}{l}\text { Data are given as median and interquartile range, if not indicated } \\
\text { otherwise. } 249 \text { patients undergone histological evaluation; }{ }^{*} \text { Pretreatment } \\
\text { serum EPO measurement was available in } 181 \text { patients: *Normal range: } \\
\text { 3.3-16.6 mIU/ml; }{ }^{1} 48 \text { patients with histological signs of severe fibrosis or } \\
\text { cirrhosis and } 15 \text { patients with clinical, biochemical and imaging evidence } \\
\text { of severe fibrosis or cirrhosis. 'Initial daily RBV dose was weight-based on a sliding } \\
\text { scale in subjects' baseline weight. Abbreviations: HCV hepatitis C virus, } \gamma-G T \\
\text { gamma-glutamyltransferase, ALT alanine transaminase, RBV ribavirin, PEG-IFN- } a \\
\text { pegylated interferon-a, SVR sustained virological response, EPO erythropoietin, } \\
\text { ITPA inosine triphosphatase. }\end{array}$} \\
\hline
\end{tabular}

When and how to treat anemia was essentially left at the discretion of the physician who treated the patient. Center specific standard operating procedures advised that treatment should be initiated when $\mathrm{Hb}$ dropped below $10 \mathrm{~g} / \mathrm{dl}$ or when the patient complained of symptoms. At the discretion of the physician anemia could be treated by blood transfusions, epoetin- $\alpha$ supplementation, RBV dose reduction or a combination thereof. During treatment the physician in charge was unaware to patients' ITPA and EPO genotypes and EPO serum concentrations as these analyses were performed only after completion of treatment.

\section{Study end points}

In accordance with previous analyses [14] we analyzed $\mathrm{Hb}$ reduction of $>3 \mathrm{~g} / \mathrm{dl}$. Differently to these previous analyses we did not only consider $\mathrm{Hb}$ reduction at week 4 weeks but also at week 12 as a composite endpoint, i.e., occurrence of an end point at either one of the time points. Furthermore, we analyzed RBV dose reduction, administration of blood transfusions or epoetin- $\alpha$ supplementation within 12 weeks of treatment as a composite event.

\section{Specific laboratory procedures}

Detection of serum HCV-specific RNA by RT-PCR and determination of $\mathrm{HCV}$ genotypes were performed as described earlier [23,24]. Serum HCV-RNA was monitored monthly.

Isolation of genomic DNA and single nucleotide polymorphism (SNP) genotyping were performed as described earlier [25]. Genotyping of EPO rs1617640 was performed by using the following primer: $36 \mu \mathrm{mol} / \mathrm{l}$ of each primer in each case; forward, 5'-AGC TAA GGT TTT ATG GCT TCT GGA A-3'; reverse 5'-GGT CTC CTG CTC TGG GAA TC-3'. Allelic discrimination was achieved by adding $8 \mu \mathrm{mol} / \mathrm{l}$ differentially fluorescent dye-labeled allele-specific minor groove binder probes (EPO: VIC, 5'-CTG AGC CAG AGG AGT GA-3'; FAM, 5' -CTG AGC CAG ATG AGT GA-3'). Genotyping of ITPA rs1127354 (ABI; NO: C_27465000) was performed according to the manufacturer's instruction.

Serum levels of EPO were measured using the Quantikine human EPO enzyme linked immunosorbent assay (ELISA; R\&D Systems, Articel-Nr: DEPOO). The assays were performed according to the manufacturer's instructions.

\section{Statistical analyses}

For this exploratory statistical analysis P-values of less than 0.05 were considered as statistically meaningful. In general, continuous variables are presented with median and interquartile range (IQR) and were analyzed by the non-parametric Mann-Whitney-U test [26]. Binary and categorical variables were compared by Pearsons chisquared test or the Cochran-Armitage Trend Test in case of ordered categorical variables [27]. Hardy-Weinbergequilibrium was tested by likelihood ratio test [28].

Multivariate logistic regression included variables that have been reported to influence $\mathrm{Hb}$ in patients on treatment, such as age, sex, and pre-treatment $\mathrm{Hb}$, viral genotype, and ribavirin starting dose $[29,30]$. The major allele of a SNP was considered to be the baseline allele (CC for ITPA rs1127354 and TT for EPO rs1617640). We primarily considered an additive genotype model for ITPA rs1127354 and a recessive model for EPO rs1617640 (with respect to the minor allele) as suggested from previous analyses [13,14,31], but dominant and co-dominant models were also considered. Backward stepwise model selection was performed based on the Akaike information criterion (AIC) [32]. The estimates are reported as odds 
ratios (OR) with confidence intervals and P-values based on the likelihood ratio. An OR above one indicates a higher risk of anemia in patients with the corresponding trait.

A linear model for the development of erythropoietin levels over time was fitted with an interaction factor of time and the minor allele of EPO rs1617640. A significant interaction of time and the $E P O$ gene variant in this model indicates a different development of erythropoietin for patients being homozygous for the minor allele compared to patients being heterozygous or homozygous for the major allele. Because of repeated measurements we confirmed the analysis in a mixed model. $P$ values cited were obtained from likelihood ratio test.

All statistical analyses were performed using the R language and environment for statistical computing version 2.15.2 [33].

\section{Results}

\section{Patient characteristics}

A total of 348 patients were included in this study. Baseline demographic, biochemical, and virological characteristics of the study cohort are listed in Table 1.

The two polymorphisms of interest, EPO rs1617640 and ITPA rs1127354, were genotyped in all patients (Table 1); genotype distributions met Hardy-Weinbergequilibrium (EPO rs1617640 $\mathrm{p}=0.75$; ITPA rs1127354 $\mathrm{p}=0.33$ ). The resulting minor allele frequencies (MAF) of
0.434 and 0.101 for EPO rs1617640 (allele G) and ITPA rs1127354 (allele A), respectively, were close to those reported for healthy Caucasian controls $[13,14]$.

\section{Serum EPO concentrations and incidence of marked $\mathrm{Hb}$} decline with regard to EPO rs 1617640 genotypes

Serum EPO concentrations at baseline were available for 181 individuals, all of them found to be within the normal range (Table 1). During therapy, concentrations raised 5 -fold by week 4 (median $43.2 \mathrm{mIU} / \mathrm{ml}$, IQR 28.70 to 68.25 ) and 14-fold by week 8 (median $106.20 \mathrm{mIU} /$ $\mathrm{ml}$, IQR 65.45 to 160.5$)$. EPO rs1617640 G homozygotes had similar baseline serum EPO concentrations when compared to $\mathrm{T}$ allele carriers (Figure 1). A linear model, however, revealed a lower rise over time in G homozygotes $(\mathrm{p}<0.001$ for interaction of time and gene variant in simple linear model and $\mathrm{p}=0.008$ in a linear mixed effects model, Figure 1).

At baseline, patients' median $\mathrm{Hb}$ concentration was within the normal range $(15.1 \mathrm{~g} / \mathrm{dl}$, IQR 14.2 to $16.0 \mathrm{~g} / \mathrm{dl})$. Median $\mathrm{Hb}$ concentration declined at week 4, 8 and 12 by -1.8 (IQR 12.1 to $14.2 \mathrm{~g} / \mathrm{dl}, \mathrm{p}<0.001$ ), -2.4 (IQR 11.4 to $13.6 \mathrm{~g} / \mathrm{dl}, \mathrm{p}<0.001$ ) and -2.6 (IQR 11.1 to $13.4 \mathrm{~g} / \mathrm{dl}$, $\mathrm{p}<0.001$ ), respectively. The cumulative frequency of patients with $\mathrm{Hb}$ reductions $>3 \mathrm{~g} / \mathrm{dl}$ at week 4,8 and 12 was $25 \%, 32 \%$ and $40 \%$, respectively (data not shown). Median baseline $\mathrm{Hb}$ levels of G homozygotes were $14.7 \mathrm{~g} / \mathrm{dl}(\mathrm{IQR}$ 14 to 15.6 ) and of T homo- and heterozygotes 15.2 (IQR

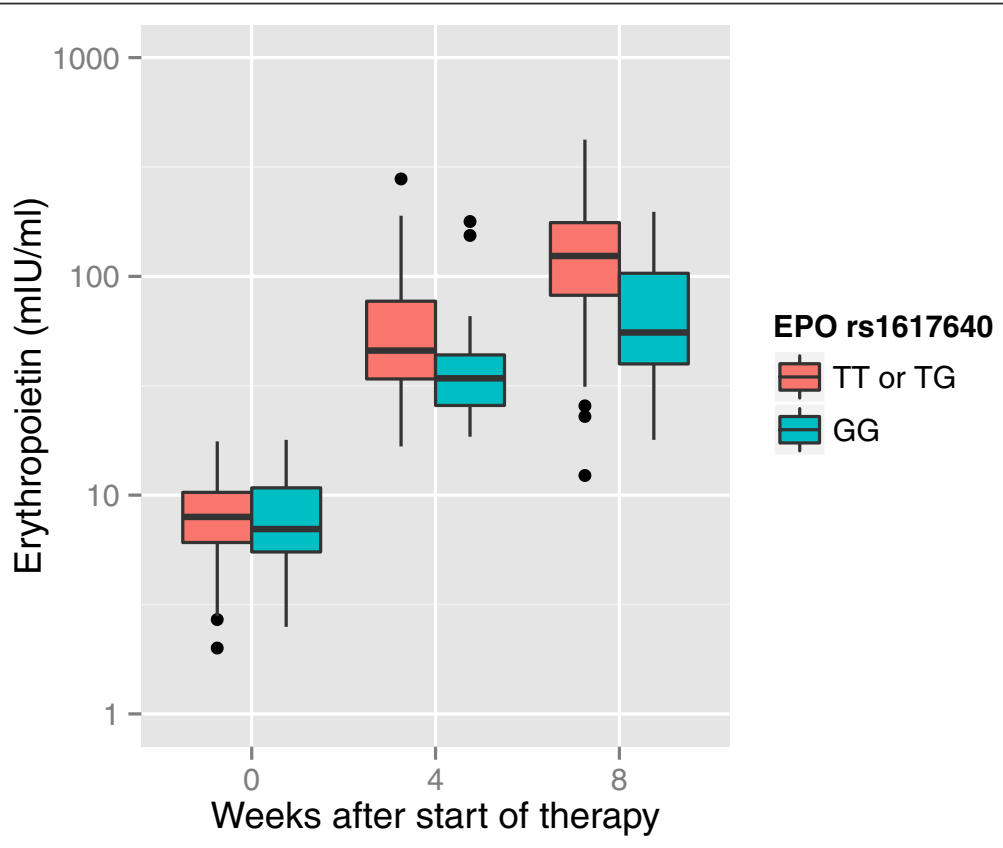

Figure 1 Pre- and on-treatment serum EPO levels with regard to EPO rs1617640 genotypes. Pretreatment serum EPO concentrations were equally distributed among major T allele carriers and minor $\mathrm{G}$ homozygotes. On-treatment serum EPO concentrations of EPO rs $1617640 \mathrm{G}$ homozygotes and T allele carriers at week 4 and 8 of therapy, however, differed significantly in a linear model. Data on serum EPO concentrations were available in 181, 112 and 78 individuals at week 0, 4 and 8, respectively. Medians and IQRs are given. 
14.2 to 16.1$)(p=0.088)$. Median baseline hematocrit levels of $\mathrm{G}$ homozygotes were $44 \%$ (IQR 42 to 45 ) and of $\mathrm{T}$ homo- and heterozygotes $43 \%$ (IQR 41 to 46 ) ( $\mathrm{p}=0.48$ ). With regard to EPO rs1617640 genotypes, $\mathrm{G}$ homozygotes experienced more frequently a marked $\mathrm{Hb}$ decline than $\mathrm{T}$ allele carriers (Figure 2A). In a univariate analysis, this difference did not reach statistical significance $(p=0.09$, $\mathrm{p}=0.09$ and $\mathrm{p}=0.1$ for weeks 4,8 and 12 , respectively). In multivariate logistic regression analyses, EPO rs1617640 allele $\mathrm{G}$ associates with an increased risk of $\mathrm{Hb}$ reduction of more than $3 \mathrm{~g} / \mathrm{dl}$ at week 4 (odds ratio (OR) 2.17, confidence interval (CI) 1.09 to $4.3, \mathrm{p}=0.025$ ) (Table 2) and week 12 (OR 1.97, CI 1.07 to 3.66, $\mathrm{p}=0.029$ ) (Table 2) of therapy, respectively. A linear regression analysis revealed the increase of serum EPO levels to be inversely associated with the decline of $\mathrm{Hb}$ levels at week 4 (Figure 3A).

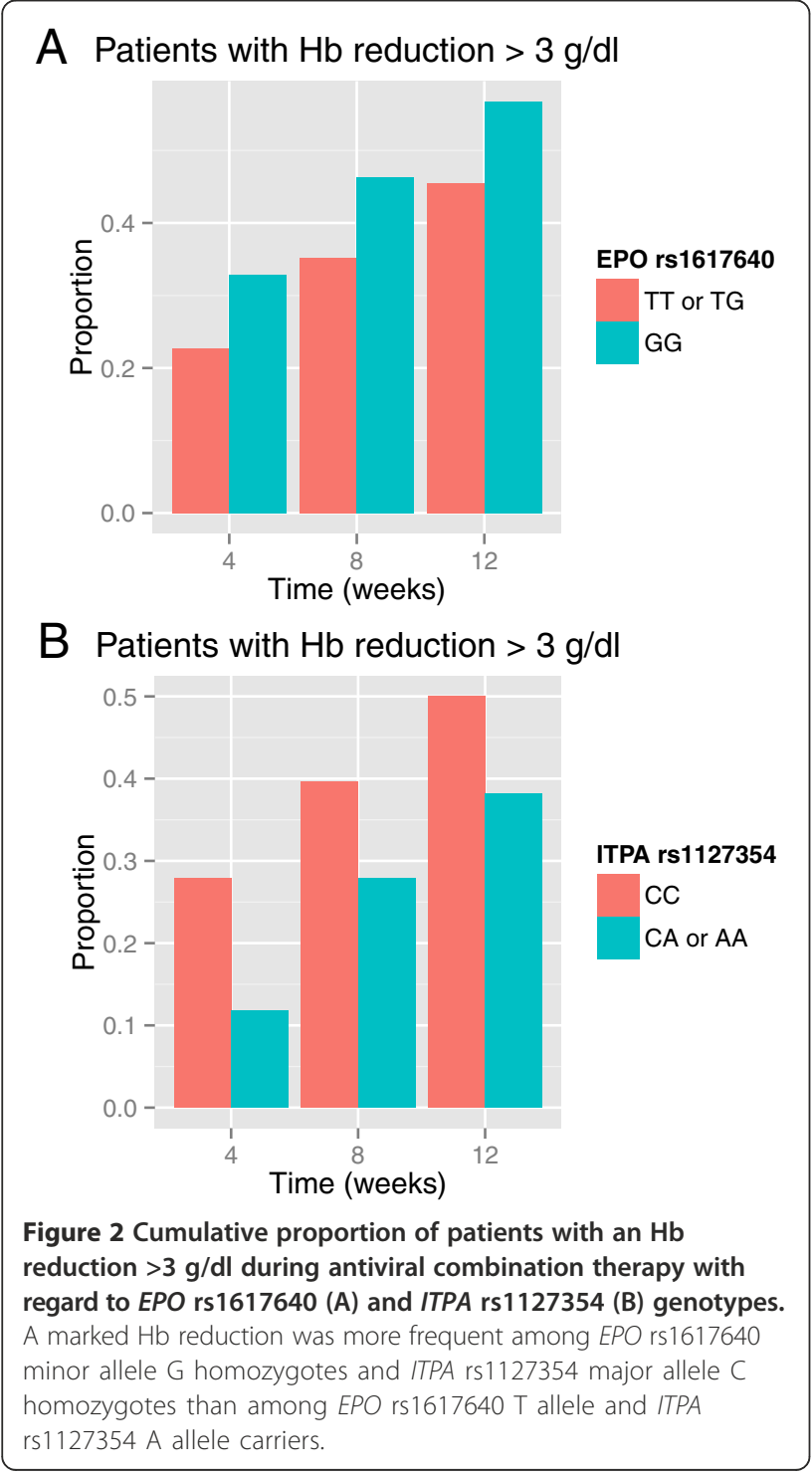

Stratification for EPO rs1617650 genotypes revealed this inverse correlation to be valid for $\mathrm{T}$ allele carriers (Figure 3C) but not for $\mathrm{G}$ homozygotes (Figure 3B). Data thus support an impact of this polymorphism on the relationship of serum EPO and Hb levels. In addition, older age, higher $\mathrm{Hb}$ values and higher $\mathrm{RBV}$ dose at the onset of therapy significantly increase the risk of patients to have $\mathrm{Hb}$ reduction at 4 and 12 weeks (Table 2), whereas viral genotype had no significant effect on $\mathrm{Hb}$ reduction (data not shown).

\section{Clinical endpoints with regard to EPO rs1617640 genotypes} Epoetin- $\alpha$ supplementation, RBV dose reduction or blood transfusions were indicated in $14 \%, 5 \%$, and $4 \%$ of patients, respectively. All three $\mathrm{Hb}$ reconstitution measures were analyzed as a composite event. An analysis with regard to EPO rs1617640 genotypes revealed $40 \%$ of $\mathrm{G}$ homozygotes to be affected by at least one of these events compared to only $14 \%$ of the $\mathrm{T}$ allele carriers $(\mathrm{p}<0.001$, Table 3$)$. Also in multivariate logistic regression, the EPO rs1617640 $\mathrm{G}$ allele strongly associated with a higher risk of an event $(\mathrm{p}<0.001)$ such as RBV dose reduction and epoetin- $\alpha$ supplementation. When we decompose the composite event and look at the single end-points we observed a significant effect of EPO rs1617640 on epoetin- $\alpha$ supplementation and RBV dose reduction $(\mathrm{p}<0.001$ for both in Pearsons chisquared test), but not for blood transfusions $(\mathrm{p}=0.366)$. $\mathrm{Hb}$ levels of EPO rs1617640 G homozygotes and the need for epoietin- $\alpha$ supplementation remained stable between week $4(11 \mathrm{~g} / \mathrm{dl}), 8(11.4 \mathrm{~g} / \mathrm{dl})$ and $12(11.5 \mathrm{~g} / \mathrm{dl})$, respectively. Other factors that are associated with the risk of a clinical event are sex (female sex: OR 0.41, CI 0.21 to $0.80, \mathrm{p}=0.003$ ) and RBV starting dose (OR 1.18, CI 1.01 to $1.39, \mathrm{p}=0.036$ ) but not baseline $\mathrm{Hb}$ (Table 4 ).

While our data revealed an association of EPO rs1617640 genotypes and the need for $\mathrm{Hb}$ reconstitution measures as one clinical endpoint, they did not unveil any relationship to baseline $\mathrm{Hb}$ level or to other clinical endpoints as histological stage of liver disease or antiviral treatment outcome (data not shown).

\section{Laboratory and clinical parameters with regard to ITPA rs1617640 variants}

The overall incidence of $\mathrm{Hb}$ reduction of more than $3 \mathrm{~g} / \mathrm{dl}$ increased steadily over a period of 12 weeks during treatment (Figure 2). ITPA rs1127354 $\mathrm{C}$ homozygotes showed an $\mathrm{Hb}$ reduction $>3 \mathrm{~g} / \mathrm{dl}$ at week 4,8 and 12 of $27 \%$, $39 \%$ and $50 \%$, respectively (Figure $2 \mathrm{~B}$ ). The risk of decreasing $\mathrm{Hb}$ levels $>3 \mathrm{~g} / \mathrm{dl}$ was significantly higher in ITPA rs1127354 $\mathrm{C}$ homozygotes compared to $\mathrm{T}$ allele carriers during treatment at week $4(\mathrm{p}=0.005)$, but less pronounced later at week 8 or $12(\mathrm{p}=0.07$ and 0.08$)$. 
Table 2 Variables associated with $\mathrm{Hb}$ reduction $>3 \mathrm{~g} / \mathrm{dl}$

\begin{tabular}{|c|c|c|c|c|}
\hline \multirow[b]{2}{*}{ Characteristics } & \multicolumn{2}{|c|}{ Univariate analysis } & \multicolumn{2}{|c|}{ Multivariate analysis } \\
\hline & Odds ratio $[95 \% \mathrm{Cl}]$ & $P$ value & Odds ratio $[95 \% \mathrm{Cl}]$ & $P$ value \\
\hline \multicolumn{5}{|l|}{ Week 4} \\
\hline EPO rs1617640 (GG vs. TT/TG) & $1.66[0.92-2.94]$ & 0.088 & $2.17[1.09-4.30]$ & 0.025 \\
\hline ITPA rs1127354 (additive) & $0.35[0.15-0.71]$ & 0.007 & $0.32[0.13-0.70]$ & 0.007 \\
\hline Age (years) & $0.97[0.95-0.99]$ & 0.0085 & $0.97[0.95-1.00]$ & 0.02 \\
\hline Sex (female vs. male) & $0.75[0.44-1.26]$ & 0.285 & $1.64[0.88-3.07]$ & 0.12 \\
\hline Baseline $\mathrm{Hb}(\mathrm{g} / \mathrm{dl})$ & $2.24[1.76-2.92]$ & $<0.001$ & $2.50[1.91-3.34]$ & $<0.001$ \\
\hline RBV starting dose* & $2.49[1.03-7.34]$ & 0.011 & $2.50[1.03-7.34]$ & 0.036 \\
\hline \multicolumn{5}{|l|}{ Week 12} \\
\hline EPO rs1617640 (GG vs. TT/TG) & $1.57[0.92-2.70]$ & 0.064 & $1.97[1.07-3.66]$ & 0.029 \\
\hline ITPA rs1127354 (additive) & $0.60[0.35-1.01]$ & 0.058 & $0.58[0.32-1.03]$ & 0.067 \\
\hline Age (years) & $0.97[0.95-0.99]$ & 0.002 & $0.97[0.95-0.99]$ & 0.004 \\
\hline Sex (female vs. male) & $0.86[0.55-1.33]$ & 0.49 & $1.75[1.04-2.99]$ & 0.084 \\
\hline Baseline $\mathrm{Hb}(\mathrm{g} / \mathrm{dl})$ & $1.90[1.55-2.35]$ & $<0.001$ & $2.08[1.67-2.64]$ & $<0.001$ \\
\hline RBV starting dose $e^{*}$ & $2.09[1.20-3.79]$ & 0.011 & $2.18[1.17-4.20]$ & 0.016 \\
\hline
\end{tabular}

Abbreviations: EPO erythropoietin, ITPA inosine triphosphatase, RBV ribavirin, $C l$ confidence interval. *RBV starting dose is coded as an ordered categorical variable with levels of $800,1000,1200$, and $1400 \mathrm{mg}$ with linear increments.

The Cochran-Armitage trend test indicated an effect of ITPA rs1127354 C allele carriers on Hb reduction at week 4 and only marginally at week 12 , with the minor allele A ameliorating anemia $(\mathrm{p}=0.005$ and $\mathrm{p}=0.056$, respectively). In multivariate logistic regression ITPA rs1127354 gene variant is associated with decreased risk of $\mathrm{Hb}$ reduction at week 4 (OR 0.32 , CI 0.13 to 0.7, $\mathrm{p}=0.007$ ) but not at week 12 (OR 0.58 , CI 0.32 to 1.03 , $\mathrm{p}=0.067)$ (Table 2). ITPA gene variation had no significant effect on clinical endpoints such as epoetin- $\alpha$ supplementation, RBV dose reduction or blood transfusions $(\mathrm{p}=0.079) \quad$ (Table 3). No interactions between EPO rs1617640 and ITPA rs1127354 could be shown by likelihood ratio test.

\section{Discussion}

The major findings of the present study are: (1) serum EPO levels of all individuals increased significantly 5 -fold at week 4 and 14-fold at week 8 compared to baseline, (2) $E P O$ rs1617640 G homozygotes showed significantly lower serum EPO levels during antiviral treatment compared to $\mathrm{T}$ allele carriers, (3) besides age, baseline $\mathrm{Hb}$ levels and RBV dose, EPO rs1617640 G allele is independently associated with $\mathrm{Hb}$ decline during antiviral treatment, (4) in $E P O$ rs1617640 $\mathrm{G}$ homozygotes the need of RBV dose reduction as well as epoetin- $\alpha$ supplementation was significantly higher compared to T allele carriers, (5) ITPA rs1127354 gene variant rather associated with $\mathrm{Hb}$ reduction at week 4 but not at week 12 and did not increase the risk of epoetin- $\alpha$ supplementation, RBV dose reduction or blood transfusion.
$\mathrm{Hb}$ decline during antiviral treatment is a frequent side effect and the reason for it is probably multifactorial. IFN- $\alpha$ induces a significant and rapid dose-dependent $\mathrm{Hb}$ decline in $\mathrm{CHC}$ patients probably by causing an inhibition of hematopoietic stem cell proliferation $[6,34,35]$. Accumulation of RBV in red blood cells may aggravate anemia by inducing hemolysis.

The most important mediator of erythropoiesis is EPO. Several reports have examined serum EPO levels during antiviral treatment and could show that serum EPO levels are increasing up to 4-fold at week 4 in patients treated with PEG-IFN- $\alpha$ and RBV while $\mathrm{Hb}$ levels are declining $[10,12]$. Our present study is consistent with these results in this respect. Here, we examined for the first time a single nucleotide polymorphism (SNP) within the EPO gene promoter, rs1617640 [13], in chronic hepatitis $C$ patients who were undergoing antiviral treatment. The $\mathrm{T}$ allele of this polymorphism had been shown to be associated with higher levels of EPO in the vitreous body fluid of nondiabetic patients than the $G$ allele [13]. The present study found $E P O$ rs1617640 G homozygotes to have an attenuated serum EPO response compared to $\mathrm{T}$ allele carriers. Moreover, EPO rs1617640 G homozygotes also had higher incidence of significant $\mathrm{Hb}$ reduction at week 4 and 12 . Finally, EPO rs1617640 G homozygotes had a significantly higher need of RBV dose reduction or epoetin- $\alpha$ supplementation, but not blood transfusion. The reason for this might be the relatively small sample number of patients who achieved blood transfusion.

Although this study investigated the EPO rs1617640 SNP with regard to a common side effect such as $\mathrm{Hb}$ 

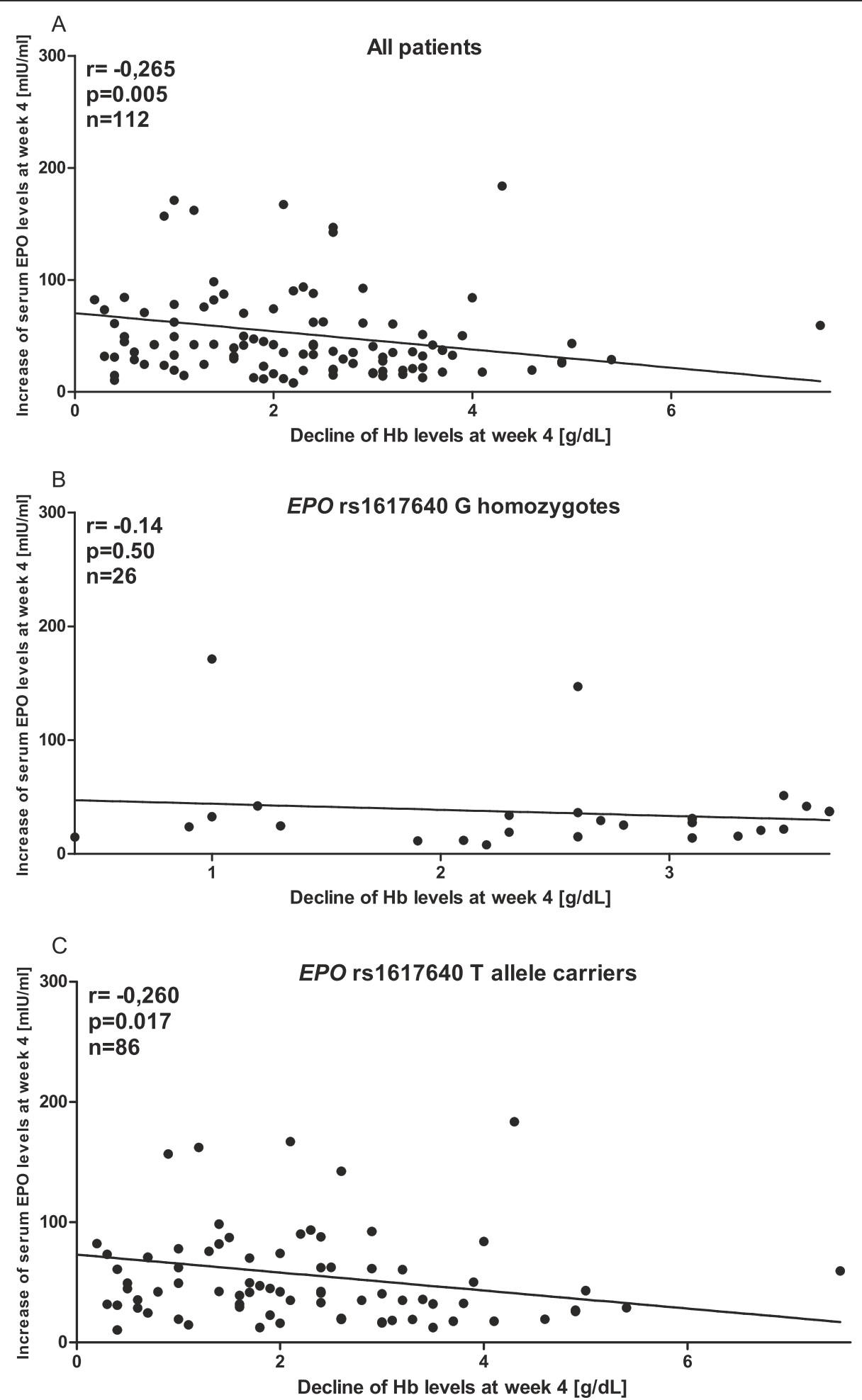

Figure 3 Linear regression analysis of serum EPO levels and Hb levels at week 4 . This analysis revealed an inverse relationship between the increase of serum EPO levels and the decline of Hb levels in 112 patients of whom data on serum EPO levels were available (A). This relationship is valid for carriers of the $T$ allele (C) but not for $\mathrm{G}$ homozygous patients (B). Correlation coefficients and levels of significance are given. 


\begin{tabular}{l} 
Table 3 Cumulative proportion of Hb reconstitution \\
measures with regard to EPO and ITPA genotypes \\
\begin{tabular}{llll}
\hline EPO rs 1617640 & $40 \%$ & $P<0.001$ \\
GG $(n=27)$ & $14 \%$ & \\
ITPA rs 1127354 & GT/TT $(n=39)$ & $21 \%$ & $P=0.079$
\end{tabular} \\
\hline
\end{tabular}

Abbreviations: $\mathrm{Hb}$ hemoglobin, EPO erythropoietin, ITPA inosine triphosphatase.

decline of antiviral therapy in $\mathrm{CHC}$ patients, our findings might not be specific for therapy of $\mathrm{CHC}$ with RBV. This SNP might directly be involved in the regulation of the $\mathrm{EPO}$ response to acute $\mathrm{Hb}$ decline in other conditions as well. Here, the role of RBV might just be in inducing an "erythropoietic stress test" taking advantage of "controlled conditions" which are not typically achievable in human research. Therefore, further research (basic and clinical) should investigate the role of the $E P O$ gene variation in various anemic diseases.

Interestingly, the $\mathrm{Hb}$ levels of $E P O$ rs $1617640 \mathrm{G}$ homozygotes who were treated with epoetin- $\alpha$ remained stable between weeks 4 to 12 . This observation suggests that substitution of EPO in patients whose $E P O$ gene activation appears to be less stimulable than in others for genetic reasons might be a rational measure and thus superior to RBV dose reduction.

A genome-wide association study has described genetic variants that are associated with a decrease of $\mathrm{Hb}$ during antiviral combination therapy at week 4 [14]. This genome-wide association study (GWAS), however, did not report associations between $\mathrm{Hb}$ reduction and any SNP within the EPO gene. Indeed, the EPO rs1617640 was not present on the Illumina Human610quad BeadChips. The only SNP in relative high linkage $\left(\mathrm{r}^{2}: 0.865\right)$ with the EPO $\mathrm{rs} 1617640$ was $\mathrm{rs} 221795$ at a 34,037 basepair distance (http://www.broadinstitute.org/ $\mathrm{mpg} / \mathrm{snap} /$ ). Moreover, GWASs are necessarily broad in scope. They search the entire genome for associations rather than focusing on small candidate areas and they do not necessarily identify all relevant SNPs [36]. Furthermore, all GWAS that evaluated SNPs for Hb decline while on treatment for $\mathrm{CHC}$ focused on end points at week 4 and could therefore only evaluate gene variations for short term $\mathrm{Hb}$ decline but not mid- to long-term $\mathrm{Hb}$ decline. This analysis shows that particularly short term $\mathrm{Hb}$ decline associates with ITPA gene variant while longer-term $\mathrm{Hb}$ decline appears to relate on $E P O$ gene variant. This hypothesizes that short and long-term $\mathrm{Hb}$ decline on treatment for HCV may have somewhat different mechanisms.

The effect of baseline $\mathrm{Hb}$ on the reduction of $\mathrm{Hb}$ on treatment is explainable by the hypothesis that reduction of $\mathrm{Hb}$ due to RBV is relative and not absolute. Therefore higher baseline $\mathrm{Hb}$ is associated with higher incidence of $\mathrm{Hb}$ reduction of more than $3 \mathrm{~g} / \mathrm{dl}$, because a reduction of $3 \mathrm{~g} / \mathrm{dl}$ is equivalent to $19 \%$ reduction when the baseline $\mathrm{Hb}$ is $16 \mathrm{~g} / \mathrm{dl}$ but $23 \%$ when the baseline $\mathrm{Hb}$ is $13 \mathrm{~g} / \mathrm{dl}$. On the other side when the end-point is formulated as $\mathrm{Hb}$ reduction below $10 \mathrm{~g} / \mathrm{dl}$ a higher baseline $\mathrm{Hb}$ is associated with a lower risk to reach this endpoint (for the same reasons). Furthermore, age is also a well-known risk factor for $\mathrm{Hb}$ reduction during antiviral therapy $[37,38]$.

The obvious constraint of this analysis is that this is a retrospective and explorative analysis of a registry data and not a formal trial. For this purpose EPO rs1617640 polymorphism should be evaluated in a prospective trial. Nevertheless, the consistency of these multiple analyses and results, i.e. association of $E P O$ gene variant with lower serum erythropoietin increase, a higher risk of $\mathrm{Hb}$ reduction, and higher incidence of adverse events suggests that EPO may indeed play an hitherto unheralded role in the treatment of $\mathrm{CHC}$.

In terms of new therapeutic options, especially in light of IFN-free regimens, $5 \%$ to $9 \%$ of patients who were treated with a DAA- and RBV-containing regimen showed increased $\mathrm{Hb}$ decline $(<10 \mathrm{~g} / \mathrm{dl})$ compared to those who were not treated with a RBV-containing regimen [39-43]. Therefore, also for IFN-free regimens with RBV, EPO rs1617640 genotyping might be worth to be valuated for estimating a risk for a marked $\mathrm{Hb}$ decline. A need to terminate these new and costly treatment options because of serious $\mathrm{Hb}$ declines is critical not least in view of inhibitor-resistance mutations.

Table 4 Variables associated with the combined clinical endpoint of RBV dose reduction, transfusion of erythrocyte concentrates, or administration of epoetin-a

\begin{tabular}{lcccc}
\hline & \multicolumn{1}{c}{ Univariate analysis } & & Multivariate analysis \\
\cline { 2 - 3 } Characteristics & Odds ratio [95\% Cl] & $\boldsymbol{P}$ value & Odds ratio [95\% Cl] & $\boldsymbol{P}$ value \\
\hline EPO rs1617640 (GG vs. TT/TG) & $4.19[2.31-7.59]$ & $<0.001$ & $4.14[2.20-7.82]$ & 0.001 \\
Sex (female vs. male) & $0.45[0.24-0.83]$ & 0.013 & $0.41[0.21-0.80]$ & 0.003 \\
Baseline Hb (g/dl) & $0.87[0.70-1.09]$ & 0.24 & $0.83[0.65-1.07]$ & 0.168 \\
RBV start dose* & $1.21[1.04-1.40]$ & 0.012 & $1.18[1.01-1.39]$ & 0.036 \\
\hline
\end{tabular}

Abbreviations: EPO erythropoietin, ITPA inosine triphosphatase, RBV ribavirin, $\mathrm{Cl}$ confidence interval. *RBV starting dose is coded as a continuous variable with an intercept at 800 and an increase of 1 in the model corresponding to $100 \mathrm{mg}$ increase of the actual dose. 


\section{Conclusion}

EPO promoter rs1617640 genotypes, serum EPO concentration and ITPA rs1127354 genotypes might be promising parameters to be further evaluated in view of a risk assessment for $\mathrm{Hb}$ decline and the individuals' capacity for an EPO response in IFN- $\alpha$ - and RBV-based therapy regimes.

\section{Competing interests}

The authors declare that they have no competing interests.

\section{Authors' contributions}

AA and SM formulated the study concept, AA and ADG made the data extraction. The statistical analysis was performed by ADG. AA, ADG and SM analyzed the research quality, interpreted data and wrote the manuscript. LR, FM and SC critically revised the manuscript for important intellectual content. All authors read and approved the final manuscript.

\section{Acknowledgments \\ The authors wish to thank all the physicians in the Department of Gastroenterology and Endocrinology who were involved in the care and control of patients. The authors would also like Ulrike Wegner, Jutta Blumberg and Waltraut Kopp for expert technical assistance. We wish to thank all the patients for allowing us to summarize the clinical data for publication.}

\section{Financial support}

This work was supported by the Deutsche Forschungsgemeinschaft (grant number Ml 474/1-1) and by the open access fund of the Georg-August-University of Goettingen, Goettingen, Germany.

\section{Author details}

'Department of Gastroenterology and Endocrinology, University Medical Center Goettingen, Robert-Koch-Strasse 40, 37075 Goettingen, Germany. ${ }^{2}$ Current address: Department of Internal Medicine, Clinic of Herzberg and Osterode, Herzberg am Harz, Germany.

Received: 7 May 2014 Accepted: 15 September 2014 Published: 17 September 2014

\section{References}

1. McHutchison JG, Lawitz EJ, Shiffman ML, Muir AJ, Galler GW, McCone J, Nyberg LM, Lee WM, Ghalib RH, Schiff ER, Galati JS, Bacon BR, Davis MN, Mukhopadhyay P, Koury K, Noviello S, Pedicone LD, Brass CA, Albrecht JK, Sulkowski MS, IDEAL Study Team, IDEAL Study Team: Peginterferon alfa-2b or alfa-2a with ribavirin for treatment of hepatitis C infection. $N$ Engl J Med 2009, 361:580-593.

2. Manns MP, McHutchison JG, Gordon SC, Rustgi VK, Shiffman M, Reindollar R, Goodman ZD, Koury K, Ling M, Albrecht JK: Peginterferon alfa-2b plus ribavirin compared with interferon alfa- $2 \mathrm{~b}$ plus ribavirin for initial treatment of chronic hepatitis C: a randomised trial. Lancet 2001, 358:958-965.

3. Fried MW, Shiffman ML, Reddy KR, Smith C, Marinos G, Goncales FL Jr, Gonçales FL Jr, Häussinger D, Diago M, Carosi G, Dhumeaux D, Craxi A, Lin A, Hoffman J, Yu J: Peginterferon alfa-2a plus ribavirin for chronic hepatitis C virus infection. N Engl J Med 2002, 347:975-982.

4. McHutchison JG, Manns MP, Muir AJ, Terrault NA, Jacobson IM, Afdhal NH, Heathcote EJ, Zeuzem S, Reesink HW, Garg J, Bsharat M, George S, Kauffman RS, Adda N, Di Bisceglie AM, PROVE3 Study Team: Telaprevir for previously treated chronic HCV infection. N Engl J Med 2010, 362:1292-1303.

5. Bacon BR, Gordon SC, Lawitz E, Marcellin P, Vierling JM, Zeuzem S, Poordad F, Goodman ZD, Sings HL, Boparai N, Burroughs M, Brass CA, Albrecht JK Esteban R, HCV RESPOND-2 Investigators: Boceprevir for previously treated chronic HCV genotype 1 infection. N Engl J Med 2011, 364:1207-1217.

6. Peck-Radosavljevic M, Wichlas M, Homoncik-Kraml M, Kreil A, Hofer H, Jessner W, Gangl A, Ferenci P, Gangl A, Ferenci P: Rapid suppression of hematopoiesis by standard or pegylated interferon-alpha. Gastroenterology 2002, 123:141-151.

7. De Franceschi L, Fattovich G, Turrini F, Ayi K, Brugnara C, Manzato F, Noventa F, Stanzial AM, Solero P, Corrocher R: Hemolytic anemia induced by ribavirin therapy in patients with chronic hepatitis $C$ virus infection: role of membrane oxidative damage. Hepatology 2000, 31:997-1004.

8. Van Soest H, Renooij W, Van Erpecum KJ: Clinical and basal aspects of anemia during antiviral therapy for hepatitis C. Ann Hepatol 2009, 8:316-324.

9. Van Vlerken LG, Van SH, Janssen MP, Boland GJ, Drenth JP, Burger DM, Siersema PD, Van Erpecum KJ: Suboptimal endogenous erythropoietin response in chronic hepatitis $C$ patients during ribavirin and PEG interferon treatment. Eur J Gastroenterol Hepatol 2010, 22:1308-1315.

10. Trivedi HS, Trivedi M: Subnormal rise of erythropoietin in patients receiving interferon and ribavirin combination therapy for hepatitis $C$. J Clin Gastroenterol 2004, 38:595-598.

11. Schmid M, Kreil A, Jessner W, Homoncik M, Datz C, Gangl A, Ferenci P, Peck-Radosavljevic M, Ferenci P, Peck-Radosavljevic M: Suppression of haematopoiesis during therapy of chronic hepatitis $C$ with different interferon alpha mono and combination therapy regimens. Gut 2005, 54:1014-1020.

12. Durante ME, Marrone A, Saviano D, Del VC, Utili R, Ruggiero G: Normal erythropoietin response in chronic hepatitis $C$ patients with ribavirin-induced anaemia. Antivir Ther 2003, 8:57-63.

13. Tong Z, Yang Z, Patel S, Chen H, Gibbs D, Yang X, Hau VS, Kaminoh Y, Harmon J, Pearson E, Buehler J, Chen Y, Yu B, Tinkham NH, Zabriskie NA, Zeng J, Luo L, Sun JK, Prakash M, Hamam RN, Tonna S, Constantine R, Ronquillo CC, Sadda S, Avery RL, Brand JM, London N, Anduze AL, King GL, Bernstein PS: Promoter polymorphism of the erythropoietin gene in severe diabetic eye and kidney complications. Proc Natl Acad Sci U S A 2008, 105:6998-7003.

14. Fellay J, Thompson AJ, Ge D, Gumbs CE, Urban TJ, Shianna KV, Little LD, Qiu P, Bertelsen AH, Watson M, Warner A, Muir AJ, Brass C, Albrecht J, Sulkowski M, McHutchison JG, Goldstein DB: ITPA gene variants protect against anaemia in patients treated for chronic hepatitis C. Nature 2010, 464:405-408.

15. Rembeck K, Waldenstrom J, Hellstrand K, Nilsson S, Nystrom K, Martner A, Lindh M, Norkrans G, Westin J, Pedersen C, Färkkilä M, Langeland N, Buhl MR, Mørch K, Christensen PB, Lagging M: Variants of the inosine triphosphate pyrophosphatase gene are associated with reduced relapse risk following treatment for HCV genotype 2/3. Hepatology 2014, 59:2131-2139.

16. Holmes JA, Roberts SK, Ali RJ, Dore GJ, Sievert W, McCaughan GW, Crawford DH, Cheng WS, Weltman MD, Bonanzinga S, Visvanathan K, Sundararajan V, Desmond PV, Bowden DS, Matthews GV, Thompson AJ, Crawford DH, Cheng WS, Weltman MD, Bonanzinga S, Visvanathan K, Sundararajan V, Desmond PV, Bowden DS, Matthews GV, Thompson AJ, CHARIOT Study Group: ITPA Genotype Protects Against Anemia During Peginterferon And Ribavirin Therapy But Does Not Influence Virological Response. Hepatology 2014, 59:2152-2160.

17. Boglione L, De NA, Cusato J, Cariti G, Di PG, D'Avolio A: Significant early higher ribavirin plasma concentrations in patients receiving a triple therapy with pegylated interferon, ribavirin and telaprevir. $J$ Viral Hepat 2014, 21:260-263.

18. Ahmed WH, Furusyo N, Zaky S, Eldin AS, Aboalam H, Ogawa E, Murata M, Hayashi J: Pre-treatment role of inosine triphosphate pyrophosphatase polymorphism for predicting anemia in Egyptian hepatitis $C$ virus patients. World J Gastroenterol 2013, 19:1387-1395

19. Ogawa E, Furusyo N, Nakamuta M, Kajiwara E, Nomura H, Dohmen K, Takahashi K, Satoh T, Azuma K, Kawano A, Tanabe Y, Kotoh K, Shimoda S, Hayashi J, Kyushu University Liver Disease Study (KULDS) Group: Clinical milestones for the prediction of severe anemia by chronic hepatitis C patients receiving telaprevir-based triple therapy. J Hepatol 2013, 59:667-674.

20. Mihm S, Fayyazi A, Hartmann H, Ramadori G: Analysis of histopathologica manifestations of chronic hepatitis $C$ virus infection with respect to virus genotype. Hepatology 1997, 25:735-739.

21. Jacobson IM, Brown RS Jr, Freilich B, Afdhal N, Kwo PY, Santoro J, Becker S, Wakil AE, Pound D, Godofsky E, Strauss R, Bernstein D, Flamm S, Pauly MP, Mukhopadhyay P, Griffel LH, Brass CA, Becker S, Wakil AE, Pound D, Godofsky E, Strauss R, Bernstein D, Flamm S, Pauly MP, Mukhopadhyay P, Griffel LH, Brass CA, WIN-R Study Group: Peginterferon alfa-2b and weight-based or flat-dose ribavirin in chronic hepatitis $C$ patients: a randomized trial. Hepatology 2007, 46:971-981.

22. Ascione A, De Luca M, Tartaglione MT, Lampasi F, Di Costanzo GG, Lanza AG, Picciotto FP, Marino-Marsilia G, Fontanella L, Leandro G: Peginterferon alfa-2a 
plus ribavirin is more effective than peginterferon alfa- $2 \mathrm{~b}$ plus ribavirin for treating chronic hepatitis C virus infection. Gastroenterology 2010, 138:116-122.

23. Mihm S, Hartmann H, Fayyazi A, Ramadori G: Preferential virological response to interferon-alpha $2 \mathrm{a}$ in patients with chronic hepatitis $C$ infected by virus genotype $3 a$ and exhibiting a low gamma-GT/ALT ratio. Dig Dis Sci 1996, 41:1256-1264.

24. Amanzada A, Goralczyk A, Moriconi F, Blaschke M, Schaefer IM, van TD, Thiel D, Mihm S, Ramadori G: Ultra-rapid virological response, young age, low gamma-GT/ALT-ratio, and absence of steatosis identify a subgroup of HCV Genotype 3 patients who achieve SVR with IFN-alpha(2a) monotherapy. Dig Dis Sci 2011, 56:3296-3304.

25. Amanzada A, Schneider S, Moriconi F, Lindhorst A, Suermann T, van Thiel DH, Mihm S, Ramadori G: Early anemia and rapid virological response improve the predictive efficiency of IL28B-genotype for treatment outcome to antiviral combination therapy in patients infected with chronic HCV genotype 1. J Med Virol 2012, 84:1208-1216.

26. Hollander M, Pena EA: Nonparametric Methods in Reliability. Stat Sci 2004, 19:644-651.

27. Ryu E, Agresti A: Modeling and inference for an ordinal effect size measure. Stat Med 2008, 27:1703-1717.

28. Evett IW, Lambert JA, Buckleton JS, Weir BS: Statistical analysis of a large file of data from STR profiles of British Caucasians to support forensic casework. Int J Legal Med 1996, 109:173-177.

29. Ochi H, Maekawa T, Abe H, Hayashida Y, Nakano R, Kubo M, Tsunoda T, Hayes CN, Kumada H, Nakamura Y, Chayama K: ITPA polymorphism affects ribavirin-induced anemia and outcomes of therapy-a genome-wide study of Japanese HCV virus patients. Gastroenterology 2010, 139:1190-1197.

30. Thompson AJ, Fellay J, Patel K, Tillmann HL, Naggie S, Ge D, Urban TJ, Shianna KV, Muir AJ, Fried MW, Afdhal NH, Goldstein DB, McHutchison JG: Variants in the ITPA gene protect against ribavirin-induced hemolytic anemia and decrease the need for ribavirin dose reduction. Gastroenterology 2010, 139:1181-1189.

31. Thompson AJ, Santoro R, Piazzolla V, Clark PJ, Naggie S, Tillmann HL, Patel K, Muir AJ, Shianna KV, Mottola L, Petruzzellis D, Romano M, Sogari F, Facciorusso D, Goldstein DB, McHutchison JG, Mangia A: Inosine triphosphatase genetic variants are protective against anemia during antiviral therapy for $\mathrm{HCV} 2 / 3$ but do not decrease dose reductions of RBV or increase SVR. Hepatology 2011, 53:389-395.

32. Venables JP: Alternative splicing in the testes. Curr Opin Genet Dev 2002, $12: 615-619$

33. Song X, Zhang BL, Liu HM, Yu BY, Gao XM, Kang LY: IQMNMR: Open source software using time-domain NMR data for automated identification and quantification of metabolites in batches. BMC Bioinformatics 2011, 12:337.

34. Wang Q, Miyakawa Y, Fox N, Kaushansky K: Interferon-alpha directly represses megakaryopoiesis by inhibiting thrombopoietin-induced signaling through induction of SOCS-1. Blood 2000, 96:2093-2099.

35. Lengfelder $E$, Berger $U$, Hehlmann R: Interferon alpha in the treatment of polycythemia vera. Ann Hematol 2000, 79:103-109.

36. Couzin-Frankel J: Major heart disease genes prove elusive. Science 2010, 328:1220-1221.

37. Reau N, Hadziyannis SJ, Messinger D, Fried MW, Jensen DM: Early predictors of anemia in patients with hepatitis $C$ genotype 1 treated with peginterferon alfa-2a (40KD) plus ribavirin. Am J Gastroenterol 2008, 103:1981-1988.

38. Sulkowski MS, Wasserman R, Brooks L, Ball L, Gish R: Changes in haemoglobin during interferon alpha-2b plus ribavirin combination therapy for chronic hepatitis C virus infection. J Viral Hepat 2004, 11:243-250.

39. Wyles DL, Rodriguez-Torres M, Lawitz E, Shiffman ML, Pol S, Herring RW, Massetto B, Kanwar B, Trenkle JD, Pang PS, Zhu Y, Mo H, Brainard DM, Subramanian GM, McHutchison JG, Habersetzer F, Sulkowski MS, Massetto B, Kanwar B, Trenkle JD, Pang PS, Zhu Y, Mo H, Brainard DM, Subramanian GM, McHutchison JG, Habersetzer F, Sulkowski MS: All-oral combination of ledipasvir, vedroprevir, tegobuvir, and ribavirin in treatment-naive patients with genotype 1 HCV infection. Hepatology 2014, 60:56-64.

40. Kowdley KV, Gordon SC, Reddy KR, Rossaro L, Bernstein DE, Lawitz E, Shiffman ML, Schiff E, Ghalib R, Ryan M, Rustgi V, Chojkier M, Herring R, Di Bisceglie AM, Pockros PJ, Subramanian GM, An D, Svarovskaia E, Hyland RH, Pang PS, Symonds WT, McHutchison JG, Muir AJ, Pound D, Fried MW, ION-3 Investigators: Ledipasvir and sofosbuvir for 8 or 12 weeks for chronic HCV without cirrhosis. N Engl J Med 2014, 370:1879-1888.
41. Afdhal N, Zeuzem S, Kwo P, Chojkier M, Gitlin N, Puoti M, Romero-Gomez M, Zarski JP, Agarwal K, Buggisch P, Foster GR, Bräu N, Buti M, Jacobson IM, Subramanian GM, Ding X, Mo H, Yang JC, Pang PS, Symonds WT, McHutchison JG, Muir AJ, Mangia A, Marcellin P, ION-1 Investigators: Ledipasvir and sofosbuvir for untreated HCV genotype 1 infection. N Engl J Med 2014, 370:1889-1898.

42. Afdhal N, Reddy KR, Nelson DR, Lawitz E, Gordon SC, Schiff E, Nahass R, Ghalib R, Gitlin N, Herring R, Lalezari J, Younes ZH, Pockros PJ, Di Bisceglie AM, Arora S, Subramanian GM, Zhu Y, Dvory-Sobol H, Yang JC, Pang PS, Symonds WT, McHutchison JG, Muir AJ, Sulkowski M, Kwo P, ION-2 Investigators: Ledipasvir and sofosbuvir for previously treated HCV genotype 1 infection. N Engl J Med 2014, 370:1483-1493.

43. Zeuzem S, Dusheiko GM, Salupere R, Mangia A, Flisiak R, Hyland RH, Illeperuma A, Svarovskaia E, Brainard DM, Symonds WT, Subramanian GM, McHutchison JG, Weiland O, Reesink HW, Ferenci P, Hézode C, Esteban R, VALENCE Investigators: Sofosbuvir and ribavirin in HCV genotypes 2 and 3. N Engl J Med 2014, 370:1993-2001.

doi:10.1186/1471-2334-14-503

Cite this article as: Amanzada et al.: Erythropoietin rs $1617640 \mathrm{G}$ allele associates with an attenuated rise of serum erythropoietin and a marked decline of hemoglobin in hepatitis $C$ patients undergoing antiviral therapy. BMC Infectious Diseases 2014 14:503.

\section{Submit your next manuscript to BioMed Central and take full advantage of:}

- Convenient online submission

- Thorough peer review

- No space constraints or color figure charges

- Immediate publication on acceptance

- Inclusion in PubMed, CAS, Scopus and Google Scholar

- Research which is freely available for redistribution

Submit your manuscript at www.biomedcentral.com/submit
C Biomed Central 